\title{
Plant growth and potassium supply dynamics on a chernozem soil of a long-term fertilization and irrigation experiment with maize monoculture in Hungary
}

Imre Vago', *, Marianna Sipos', Laszlo Tolner², Imre Czinkota², Gergely Szilagyi , Ibrahim Issa, Janos Katai ${ }^{1}$

1 University of Debrecen, Faculty of Agricultural, Food Sciences and Environmental Management, Institute of Agricultur Chemistry and Soil Science, Debrecen, Hungary

2 Szentlstván University, Department of Soil Science and Agricultural Chemistry, Gödöllö, Hungary

3 University of Debrecen, Faculty of Agricultural, Food Sciences and Environmental Management, 1 alnstitute of Crop Sciences, Debrecen, Hungary

4 Sirte University, Agriculture Faculty, Department of Soil and Water, Sirte, Libya

*Corresponding author e-mail : vago@agr.unideb.hu

Received : 13.12.2013

Accepted: 14.04 .1014

\section{Abstract}

For the plant production used soil's nutrient supplying ability ideally should correspond to the needs of the plants. The aim of our experiment work is to study as precisely as possible, how the dynamics of growth and nutrient uptake of the maize plant develop during the vegetation period. For their determination the basis of our research work was a long-term irrigation and fertilization monoculture maize field experiment that has been set up in 1984 near to Debrecen, Hungary. The soil of this experiment is a medium-heavy, loam texture calcareous chernozem type based on loess. The deepness of humus soil layer is between 70 and $90 \mathrm{~cm}$. Its upper layer has become leached due to the intensive production in the past decades, so it doesn't content any significant lime-amount. Therefore, the soil pH is slightly acidic in the production layer, which is favorable for nutrient-mobilization and -uptake. This field represents the production circumstances of the chernozem soils of Hungary with excellent productivity. Effects of three factors were studied: genotypes of maize (3), fertilizer dosages (6) and irrigation levels (2). The total number of investigated treatments (plots) was 36. Plant samples were collected 7 or 6 times during the vegetation period, and the above-ground dry matter and the nutrient uptake of plants were determined. For characterizing and describing of the plant growth and nutrient uptake dynamics was used the so-called "S-type" (acceleration - saturation) equation as follows: $y=A\left(1+\exp \left(-k^{*}(x-x 0)\right)\right)^{*}\left(1-b^{*} x\right)$, where " $y^{\prime \prime}$ is the actual value of the measured (dependent) factor on the day " $\mathrm{x}$ " after plant shooting, " $\mathrm{A}$ " is the maximum value of " $\mathrm{y}$ ", " $\mathrm{x} 0$ " is the day of maximum growth rate of " $y$ " (point of inflexion) and " $b$ " is the rate of decreasing of dependent value for one unit. According to our results and calculations it can be concluded, that beside the previously used soil and plant nutrientcontent the consideration and calculation of the plant-extracted nutrient-amount - depending on the applied hybrid and other agro-technological measurements - is suggested in order to characterize precisely the nutrient-supply of maize. This parameter informs us not only about the available nutrientamount at the sampling time, but about the supply level of the plants until the sampling time as well. We suggest for sampling times the intensive vegetative growth period, the switch between the vegetative and generative growth phases (silking), just as the grain-filling phase.

Keywords: Chernozem, maize, biomass and potassium uptake dynamics

\section{INTRODUCTION}

The nutrient supplying ability of soil ideally should correspond to the needs of plants, which change dynamically during the plant growth phases (BERGMANN \& NEUBERT, 1976; KÁDÁR \&

LÁSZTiTY, 1981; BUZÁs, 1987). The aim of the present research work was to study during the vegetation period of maize produced for grain, how the dynamics of growth and nutrient uptake 
of the plant change. Based on these results it is possible to follow and determine the nutrient supply of soils during vegetation, just like all the effects influencing it. Not only the growth of plants, but the change in their nutrient-demand over time can be studied, which can be taken into account in general characterization and in fertilization.

Similar studies were carried out previously by TOLNER et al. (1982) in Hungary. They studied the growth and nutrient uptake dynamics of Lolium perenne $\mathrm{L}$. in a pot experiment. The kinetics of the cumulated nitrogen uptake dynamics of the perennial ryegrass plant material harvested at different vegetation stages were described successfully by a model of a first-order process. In case of phosphorus uptake the increasing phase at the beginning of vegetation was attributed to the increase in the speed of phosphorus uptake, related to root development, and a function was used in their model as well.

BiczÓk et al. (1985) elaborated a phenomenological model to describe the dynamics of plant dry matter accumulation. The bio-mathematical model used for the calculations included two compartments. One of them was a logistical function that is well-known and widely used for the description of autocatalytic processes in chemistry and mainly for the description of biological growth. The other compartment was similar to the first function, although with a negative sign, making it possible to describe the decreasing nutrient contents at the end of plant vegetation. The represented model was successfully used for the modelling of dry matter accumulation (LÁSZTiTY et al., 1985a) and nutrient uptake (LÁSZTiTY et al., 1985b) of maize.In the present publication the effects of genotypes, nutrient supply and irrigation level on the dry matter production and potassium uptake dynamics of maize (Zea mays L.) were studied on the fertile, in the deep layers calcareous chernozem soil of the Debrecen-Látókép longterm field experiment (Eastern Hungary).

\section{Material and Methods}

As the long-term field experiments are suitable for following changes in soil and plant characteristics (GYŐRi et al., 2005), for the basis of present research work was chosen a long-term fertilization and irrigation monoculture maize field experiment, which was set up in 1984 near to Debrecen, Eastern part of Hungary (NAGY, 1997). Some properties of the medium-heavy, loamy calcareous chernozem soil based on loess are as follows: $K_{A}$ (upper limit of plasticity according to Arany, determined according to BUZÁS, 1988): 39; humus soil layer: $70-90 \mathrm{~cm}$; humus content: $2.4 \%$; total carbon content: 1.89\%; ammonium lactate soluble P content: 101 mg $\mathrm{P}_{2} \mathrm{O}_{5} \cdot \mathrm{kg}^{-1}$; ammonium lactate soluble $\mathrm{K}$ content: $232.4 \mathrm{mg} \mathrm{K}_{2} \mathrm{O} \mathrm{kg}$. The soil has a sufficient natural nitrogen supply, a rather weak phosphorus supply and medium potassium supply. Due to the intensive production in the past decades, its upper $30 \mathrm{~cm}$ layer has become leached, so its $\mathrm{CaCO}_{3}$ content is insignificant. Therefore, under stressed conditions such as drought, soil acidity, etc., it can buffer and compensate the negative effects of the unfavourable circumstances only to a limited extent. The soil $\mathrm{pH}\left(\mathrm{H}_{2} \mathrm{O}\right)$ value is 6.05 , slightly acidic in the production layer, which is mostly favourable from the aspect of nutrient mobilization and nutrient uptake. The minimal water retention capacity of soil is $27-29 \mathrm{~V} / \mathrm{V} \%$. The experimental field represents the main production conditions of chernozem soils with excellent productivity in the region of Eastern Hungary.

The experimental site consists of two parts: one half - in most years, if necessary - can be irrigated, the other half is non-irrigated, on which only the water amount from natural precipitation and the stored moisture content of soil are available for plants. This makes it possible to determine the effects of different crop years, just as weather anomalies, and gather information on the achievable yield increment in case the plants' demand is satisfied in the critical periods.

The selection of maize hybrids for the study was based on the length of their vegetation period (FAO number). Three hybrids (all of them were bread by the Agricultural Institute, Centre for Agricultural Research, Hungarian Academy of Sciences, Martonvásár) with varying vegetation periods were used: Mv 251 (FAO 280), Mv Koppány (FAO 420) and Mv 500 (FAO 510), as according to authors' hypothesis and knowledge there are characteristic differences in both the extent and the dynamics of their nutrient uptake. 
In the four-repetition small-plot long-term field experiment the effects of macronutrient fertilization are studied - in addition to the control variant - on five nutrient levels with fixed 1.0:0.77:0.90 $\mathrm{N}: \mathrm{P}_{2} \mathrm{O}_{5}: \mathrm{K}_{2} \mathrm{O}$ rate; the yearly applied nitrogen doses being $0,30,60,90,120$ and $150 \mathrm{~kg} \mathrm{~N}$.ha-1, respectively. The total number of investigated treatments (plots) was 2 water supply levels $\times 3$ genotypes $\times 6$ fertilization levels $=36$ in both experimental years. The total number of plant samples collected 7 times (in 2008) and 6 times (in 2009) during the vegetation period - amounted to 252 and 216 in the studied years, respectively. At the first sampling time 8 , at the second 6 , at the third 4 , and at all of the remaining 4 or 3 sampling times 2 maize plants were collected per plot. The total above-ground dry matter mass was determined. The dried shoots were grinded, homogenized and analysed for their nutrient element contents. The nutrient uptakes of shoots up to each sampling time were calculated.

\section{Results and Discussion}

For the description and characterization of maize plant growth and nutrient uptake dynamics, several classical types of equations were analysed. According to the results, authors worked out a new combined function that was the most suitable for their purposes, the so-called "S-type" (acceleration - saturation) equation, as follows:

$$
y=\frac{A \cdot(1-b \cdot x)}{1+e^{-k \cdot(x-x 0)}}
$$

where: the variable $y$ is the actual value of the measured (dependent) factor (t ha-1 or $\mathrm{kg} \mathrm{ha}^{-1}$ ), $\mathrm{x}$ is the day after plant shooting (days); the parameter $A$ is the maximum value of $y(t) \mathrm{ha}^{-1}$ or $\mathrm{kg} \mathrm{ha-1}), x 0$ is the day of maximum growth rate of $y$, which is the point of inflexion, (days), $b$ is the rate of decrease of the dependent value by one unit $\left(\right.$ days $\left.^{-1}\right) ; k$ is the growth constant $\left(\right.$ days $^{-1}$ ).

The theory of deriving this equation (1) was: this system is the combination of a biological growth (logistic part of function) and a decreasing commensurable to the size of plant (linear decreasing part of function).

\section{Biomass Production}

The amount of produced biomass of maize (Figure 1) was mainly determined by the weather conditions, which basically differed in the studied two vegetation periods.

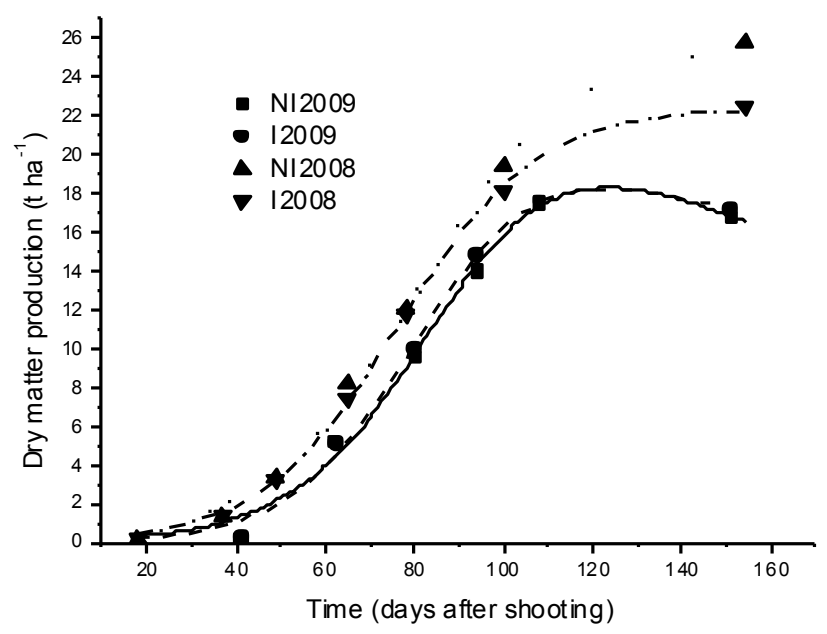

Figure 1. Dry matter production (t ha-1) of maize in nonirrigated (NI) and irrigated (I) treatments of the long-term field experiment (Debrecen-Látókép, Hungary) during its vegetation period in 2008 and 2009, on the average of nutrient supply levels and hybrids

In 2008, as the amount of precipitation in the vegetation period of maize was quite high for the Hungarian conditions (420 mm), no irrigation was required in any of the treatments. Nevertheless, the differences between the dry matter production of previously irrigated and non-irrigated treatments were significant: the yields of non-irrigated plots (most upper curve) were higher than those of the previously irrigated treatments of the long-term field experiment (second curve top-down). Earlier, the produced yields of non-irrigated treatments had regularly been lower than those of the methodically irrigated ones, which lead to the fact that - from the time the long-term experiment was set up in 1984 - plant biomass had extracted smaller amounts of nutrients from the soil of the nonirrigated treatments. In the 2009 crop year the dry matter production of maize was lower during the whole vegetation (Table 1), in contrast to the previous crop year (Table 2). 
Table 1. Shoot and grain production of maize (t ha") grown in 2009 (“dry" vegetation period) in the irrigated and nonirrigated treatments of the long-term fertilization field experiment in Debrecen-Látókép, Hungary

\begin{tabular}{|c|c|c|c|c|c|c|c|c|c|}
\hline \multirow{3}{*}{$\begin{array}{l}\text { Water } \\
\text { supply }\end{array}$} & \multirow{3}{*}{ Hybrid } & \multirow{3}{*}{ Fertilization } & \multicolumn{6}{|c|}{ Dry matter of produced shoots, $\mathrm{t} \mathrm{ha}^{-1}$} & \multirow{3}{*}{$\begin{array}{l}\text { Grain yield, } \\
\text { t ha }^{-1}\end{array}$} \\
\hline & & & $1^{\mathrm{st}}$ & $2^{\text {nd }}$ & $3^{\text {rd }}$ & $4^{\text {th }}$ & $5^{\text {th }}$ & $6^{\text {th }}$ & \\
\hline & & & \multicolumn{6}{|c|}{ sampling time } & \\
\hline \multirow{18}{*}{ 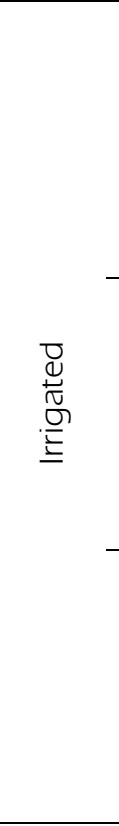 } & \multirow{6}{*}{$\begin{array}{l}\stackrel{\bar{n}}{\cong} \\
\stackrel{z}{z}\end{array}$} & control & 0.23 & 4.2 & 9.28 & 10.5 & 12.08 & 11.03 & 2.75 \\
\hline & & $\mathrm{N}_{30}$ & 0.21 & 5.25 & 7.88 & 12.6 & 13.13 & 12.95 & 4.85 \\
\hline & & $\mathrm{N}_{60}$ & 0.25 & 5.25 & 9.1 & 15.58 & 16.45 & 16.28 & 5.59 \\
\hline & & $\mathrm{N}$ & 0.23 & 5.78 & 10.85 & 16.1 & 17.85 & 18.2 & 6.38 \\
\hline & & $N_{120}$ & 0.26 & 5.78 & 10.68 & 18.2 & 19.6 & 19.43 & 5.91 \\
\hline & & $\mathrm{N}_{150}$ & 0.38 & 5.95 & 11.55 & 15.75 & 21.18 & 21.35 & 6.81 \\
\hline & \multirow{6}{*}{$\begin{array}{l}\frac{\lambda}{\sqrt{n}} \\
0 \\
0 \\
0 \\
\frac{0}{2} \\
\dot{z}\end{array}$} & control & 0.18 & 3.85 & 7.0 & 10.85 & 13.65 & 13.48 & 5.41 \\
\hline & & $\mathrm{N}_{30}$ & 0.17 & 3.85 & 8.93 & 14.53 & 13.3 & 13.3 & 6.25 \\
\hline & & $N_{60}$ & 0.12 & 5.08 & 11.73 & 16.28 & 19.25 & 19.43 & 7.24 \\
\hline & & $\mathrm{N}_{90}$ & 0.31 & 6.13 & 10.5 & 16.63 & 20.13 & 20.48 & 8.27 \\
\hline & & $\mathrm{N}_{120}$ & 0.22 & 6.48 & 13.3 & 168 & 22.4 & 23.1 & 8.41 \\
\hline & & $\mathrm{N}_{150}$ & 0.19 & 6.13 & 14.0 & 16.1 & 22.05 & 22.58 & 8.58 \\
\hline & \multirow{6}{*}{$\sum$} & control & 0.15 & 4.2 & 7.53 & 10.85 & 12.6 & 12.08 & 4.08 \\
\hline & & $N_{30}$ & 0.17 & 3.5 & 7.7 & 10.85 & 14.53 & 14.18 & 6.17 \\
\hline & & $N_{60}$ & 0.21 & 4.9 & 9.28 & 14.0 & 18.73 & 14.35 & 6.60 \\
\hline & & $\mathrm{N}_{90}$ & 0.19 & 3.85 & 9.8 & 16.45 & 18.55 & 17.85 & 7.17 \\
\hline & & $\mathrm{N}_{120}$ & 0.25 & 5.95 & 10.33 & 17.68 & 21.53 & 20.83 & 7.85 \\
\hline & & $\mathrm{N}_{150}$ & 0.25 & 6.13 & 9.63 & 17.5 & 19.43 & 18.73 & 8.08 \\
\hline \multirow{18}{*}{ 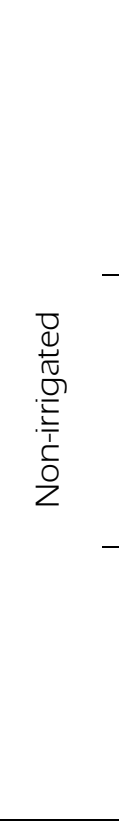 } & \multirow{6}{*}{$\begin{array}{l}\stackrel{\bar{n}}{\cong} \\
\stackrel{2}{\Sigma}\end{array}$} & control & 0.13 & 4.38 & 5.6 & 11.9 & 11.03 & 11.55 & 2.31 \\
\hline & & $N_{30}$ & 0.2 & 5.43 & 7.7 & 10.5 & 15.75 & 13.65 & 4.46 \\
\hline & & $\mathrm{N}_{60}$ & 0.13 & 4.55 & 8.05 & 13.13 & 15.93 & 15.58 & 5.03 \\
\hline & & $\mathrm{N}_{90}$ & 0.28 & 5.78 & 10.5 & 126 & 19.95 & 19.95 & 4.59 \\
\hline & & $\mathrm{N}_{120}$ & 0.26 & 6.48 & 11.2 & 15.58 & 18.03 & 21.18 & 5.28 \\
\hline & & $\mathrm{N}_{150}$ & 0.32 & 5.78 & 10.5 & 14.53 & 17.15 & 21.18 & 5.48 \\
\hline & \multirow{6}{*}{ 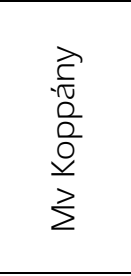 } & control & 0.16 & 4.2 & 9.45 & 12.95 & 15.05 & 15.4 & 5.26 \\
\hline & & $N_{30}$ & 0.18 & 3.85 & 7.7 & 11.73 & 18.38 & 17.15 & 5.95 \\
\hline & & $N_{60}$ & 0.27 & 5.6 & 9.28 & 14.7 & 19.95 & 16.8 & 7.05 \\
\hline & & $\mathrm{N}_{20}$ & 0.27 & 5.6 & 10.68 & 15.75 & 21.0 & 19.95 & 6.97 \\
\hline & & $N_{120}$ & 0.21 & 5.95 & 11.9 & 20.3 & 19.25 & 19.25 & 7.03 \\
\hline & & $\mathrm{N}_{150}$ & 0.33 & 6.65 & 12.6 & 20.3 & 25.9 & 18.9 & 8.56 \\
\hline & \multirow{6}{*}{$\begin{array}{l}8 \\
\text { ำ } \\
\geq \\
\sum\end{array}$} & control & 0.15 & 3.85 & 7.7 & 9.45 & 11.38 & 10.85 & 3.91 \\
\hline & & $N_{30}$ & 0.18 & 49 & 9.45 & 15.4 & 12.6 & 112 & 5.45 \\
\hline & & $N_{60}$ & 0.18 & 3.68 & 7.0 & 12.6 & 12.95 & 13.3 & 6.5 \\
\hline & & $N_{90}$ & 0.2 & 5.6 & 9.1 & 12.43 & 19.43 & 19.43 & 6.87 \\
\hline & & $N_{120}$ & 0.17 & 5.95 & 12.25 & 12.43 & 19.25 & 19.6 & 6.96 \\
\hline & & $N_{150}$ & 0.22 & 5.95 & 11.38 & 16.1 & 22.58 & 17.15 & 7.89 \\
\hline
\end{tabular}

Remarks: Fertilization levels control: no fertilizer applied; $\quad N_{30}: 30,23,27 ; \quad N_{60}: 60,46,54 ; \quad N_{90}: 90,69,81 ; \quad N_{120}: 120$, 92,$108 ; \mathrm{N}_{150}: 150,115,135 \mathrm{~kg} \cdot \mathrm{ha}^{-1} \mathrm{~N}, \mathrm{P}_{2} \mathrm{O}_{5}, \mathrm{~K}_{2} \mathrm{O}$, respectively 
Table 2. Shoot and grain production of maize (t.ha' ${ }^{-1}$ grown in 2008 (“wet” vegetation period) in the irrigated and nonirrigated treatments of the long-term fertilization field experiment in Debrecen-Látókép, Hungary

\begin{tabular}{|c|c|c|c|c|c|c|c|c|c|c|}
\hline \multirow{3}{*}{$\begin{array}{l}\text { Water } \\
\text { supply }\end{array}$} & \multirow{3}{*}{ Hybrid } & \multirow{3}{*}{ Fertilization } & \multicolumn{7}{|c|}{ Dry matter of produced shoots, $\mathrm{t} \mathrm{ha}^{-1}$} & \multirow{3}{*}{$\begin{array}{l}\text { Grain } \\
\text { yield, } \\
\mathrm{t} \cdot \mathrm{ha}^{-1}\end{array}$} \\
\hline & & & $1^{\text {st }}$ & $2^{\text {nd }}$ & $3^{\text {rd }}$ & $4^{\text {th }}$ & $5^{\text {th }}$ & $6^{\text {th }}$ & $7^{\text {th }}$ & \\
\hline & & & \multicolumn{7}{|c|}{ sampling time } & \\
\hline \multirow{18}{*}{ 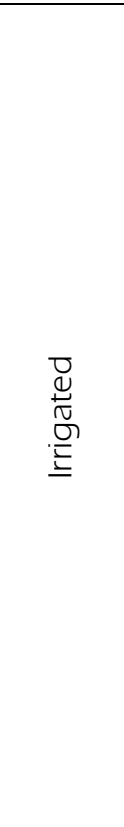 } & \multirow{6}{*}{$\begin{array}{l}\stackrel{\bar{n}}{N} \\
\stackrel{2}{\Sigma}\end{array}$} & control & 0.18 & 1.62 & 2.12 & 4.55 & 7.0 & 9.8 & 10.15 & 4.89 \\
\hline & & $\mathrm{N}_{30}$ & 0.15 & 1.29 & 2.74 & 5.9 & 8.05 & 16.8 & 17.5 & 5.29 \\
\hline & & $N_{60}$ & 0.14 & 1.54 & 3.74 & 6.05 & 12.6 & 16.1 & 182 & 7.06 \\
\hline & & Noo & 0.14 & 1.34 & 3.56 & 6.65 & 11.2 & 22.4 & 23.1 & 7.29 \\
\hline & & $N_{120}$ & 0.23 & 1.43 & 3.1 & 9.1 & 15.75 & 22.4 & 24.15 & 8.39 \\
\hline & & $\mathrm{N}_{150}$ & 0.23 & 1.73 & 3.75 & 9.45 & 12.25 & 22.05 & 22.75 & 8.78 \\
\hline & \multirow{6}{*}{$\begin{array}{l}\vec{d} \\
-\frac{1}{0} \\
\stackrel{0}{0} \\
\frac{0}{2} \\
\dot{z}\end{array}$} & control & 0.13 & 1.21 & 2.05 & 4.9 & 7.35 & 9.45 & 13.3 & 5.84 \\
\hline & & $\mathrm{N}_{30}$ & 0.16 & 1.17 & 2.33 & 6.65 & 98 & 16.1 & 17.5 & 79 \\
\hline & & $N_{60}$ & 0.21 & 1.39 & 3.28 & 9.45 & 10.85 & 19.25 & 25.2 & 9.72 \\
\hline & & Nop & 0.21 & 1.18 & 3.83 & 9.37 & 14.35 & 22.05 & 22.4 & 9.61 \\
\hline & & $\mathrm{N}_{120}$ & 0.19 & 1.32 & 4.0 & 8.22 & 15.05 & 22.05 & 22.75 & 10.87 \\
\hline & & $N_{150}$ & 0.21 & 1.88 & 4.29 & 9.1 & 15.4 & 23.1 & 30.45 & 11.46 \\
\hline & \multirow{6}{*}{$\begin{array}{l}\text { ○ } \\
\text { @ } \\
3 \\
\sum\end{array}$} & control & 0.12 & 1.44 & 2.38 & 4.55 & 6.3 & 8.05 & 17.85 & 5.24 \\
\hline & & $N_{30}$ & 0.13 & 0.85 & 2.78 & 5.6 & 12.6 & 9.1 & 21.0 & 7.29 \\
\hline & & $N_{60}$ & 0.15 & 0.99 & 2.7 & 6.73 & 10.5 & 18.2 & 27.65 & 9.68 \\
\hline & & No. & 0.16 & 1.11 & 3.38 & 7.7 & 15.75 & 217 & 35.35 & 9.5 \\
\hline & & $N_{120}$ & 0.16 & 1.29 & 2.66 & 9.8 & 14.7 & 24.15 & 28.0 & 12.27 \\
\hline & & $N_{150}$ & 0.2 & 1.29 & 4.48 & 10.5 & 13.3 & 24.5 & 25.55 & 13.05 \\
\hline \multirow{18}{*}{ 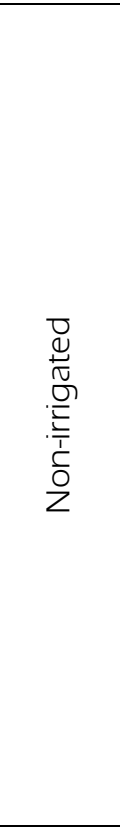 } & \multirow{6}{*}{$\begin{array}{l}\stackrel{\bar{n}}{N} \\
\stackrel{z}{z}\end{array}$} & control & 0.16 & 1.27 & 2.38 & 5.25 & 6.3 & 12.6 & 14.7 & 6.3 \\
\hline & & $N_{30}$ & 0.13 & 1.49 & 2.89 & 6.3 & 8.75 & 17.5 & 23.8 & 7.12 \\
\hline & & $N_{60}$ & 0.21 & 1.47 & 2.68 & 8.4 & 13.3 & 19.95 & 23.8 & 9.97 \\
\hline & & Noo & 0.27 & 1.58 & 3.8 & 10.15 & 119 & 210 & 21.7 & 9.06 \\
\hline & & $N_{120}$ & 0.25 & 1.6 & 4.28 & 98 & 12.95 & 22.05 & 33.95 & 10.57 \\
\hline & & $\mathrm{N}_{150}$ & 0.19 & 1.75 & 4.81 & 12.25 & 17.85 & 21.0 & 25.9 & 10.54 \\
\hline & \multirow{6}{*}{ 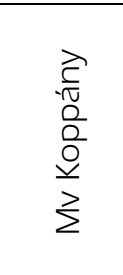 } & control & 0.17 & 1.45 & 1.75 & 4.55 & 8.75 & 11.55 & 20.3 & 9.32 \\
\hline & & $N_{30}$ & 0.21 & 1.51 & 3.19 & 7.7 & 11.55 & 16.45 & 23.45 & 11.44 \\
\hline & & $N_{60}$ & 0.25 & 1.41 & 3.43 & 8.05 & 11.55 & 17.85 & 21.0 & 12.35 \\
\hline & & $N_{90}$ & 0.23 & 1.46 & 4.04 & 9.1 & 13.65 & 22.05 & 28.7 & 12.21 \\
\hline & & $\mathrm{N}_{120}$ & 0.2 & 1.48 & 3.97 & 8.75 & 12.95 & 21.7 & 30.8 & 13.28 \\
\hline & & $\mathrm{N}_{150}$ & 0.2 & 1.8 & 4.8 & 8.75 & 14.7 & 23.45 & 31.5 & 12.73 \\
\hline & \multirow{6}{*}{$\begin{array}{l}8 \\
\text { ำ } \\
\dot{z}\end{array}$} & control & 0.1 & 1.54 & 1.94 & 7.0 & 8.4 & 15.05 & 15.75 & 7.46 \\
\hline & & $N_{30}$ & 0.14 & 0.97 & 3.16 & 7.7 & 10.15 & 19.95 & 31.85 & 9.79 \\
\hline & & $N_{60}$ & 0.17 & 0.99 & 2.8 & 7.0 & 12.25 & 19.25 & 22.4 & 1135 \\
\hline & & $N_{90}$ & 0.16 & 1.39 & 2.51 & 7.24 & 12.6 & 18.55 & 32.9 & 12.14 \\
\hline & & $N_{120}$ & 0.17 & 0.97 & 4.3 & 98 & 16.1 & 25.2 & 25.55 & 14.48 \\
\hline & & $\mathrm{N}_{150}$ & 0.16 & 1.35 & 3.92 & 10.5 & 13.3 & 24.15 & 36.4 & 14.35 \\
\hline
\end{tabular}

Remarks: Fertilization levels control: no fertilizer applied; $N_{30}: 30,23,27 ; \quad N_{60}: 60,46,54 ; \quad N_{90}: 90,69,81 ; \quad N_{120}: 120$, 92, 108; $\mathrm{N}_{150}: 150,115,135 \mathrm{~kg} \cdot \mathrm{ha}^{-1} \mathrm{~N}, \mathrm{P}_{2} \mathrm{O}_{5}, \mathrm{~K}_{2} \mathrm{O}$, respectively

In this period the amount of relevant precipitation was only $167 \mathrm{~mm}$, making the application of irrigation essential in the respective treatments. Nevertheless, regarding the average of the genotypes and nutrient supply levels, the extent and dynamics of maize biomass production was practically similar (see the two 2009 curves on Figure 1). The application of $50 \mathrm{~mm}$ irrigation water (25 mm irrigation water was added 2 times) had no significant effect on dry matter accumulation in this year.

The possible reason for this is that the average temperature between April and the harvest was consequently $3-5^{\circ} \mathrm{C}$ higher than the respective 30year average values. The curves in Figure 2 show that the dry matter production of the three hybrids differed 
significantly. In the first 90-95 days of the 2008 crop year (upper three curves) there was no difference between the hybrids, but at the end of vegetation the difference in the genetic potential of the hybrids manifested highly, parallel to their increasing FAO-number their dry matter production increased as well. The difference between Mv 251 and Mv 500 hybrids was more than $5 \mathrm{t} \mathrm{ha}^{-1}$ in this year.

In the 2009 crop year - due to the dry and warm weather conditions - Mv 500 did not produce the yield expectable of its genetic potential, while the lowest yield loss - in contrast to that of year 2008 - was recorded for Mv Koppány (the hybrid with lower demand).

On Figures 3 and 4 it can be observed that according to authors' hypothesis - on the average of the genotypes and water supply, the dry matter yield increasing effect of NPK supply could be observed in both crop years.

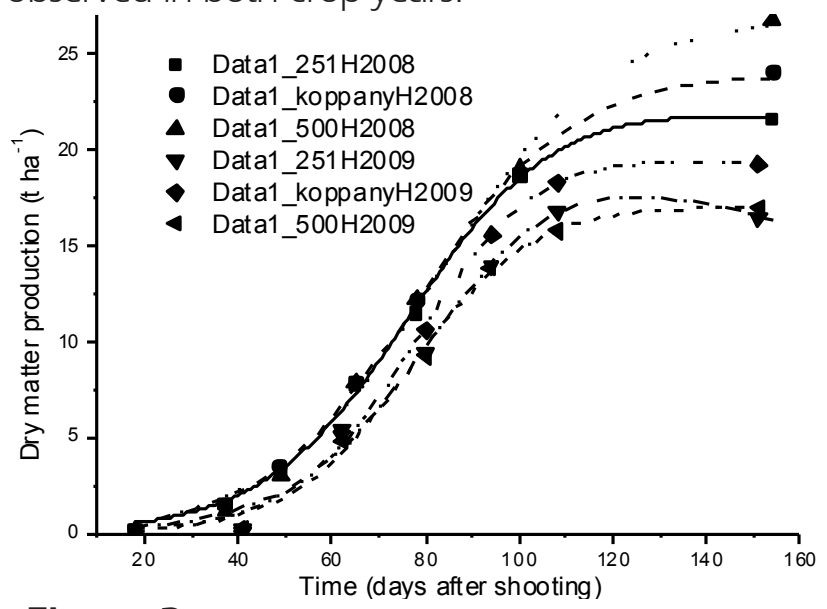

Figure 2. Dry matter production (t.ha' ${ }^{-1}$ ) of the Mv 251 Mv-Koppány and Mv500 maize hybrids grown in 2008 and 2009 crop years in the long-term fertilization field experiment in Debrecen-Látókép, Hungary, on the average of nutrient and water supply

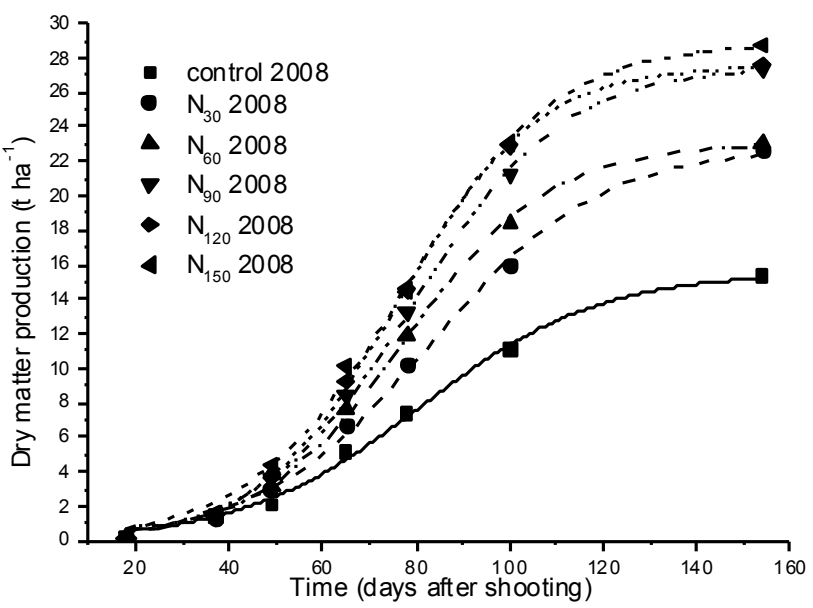

Figure 3. Dry matter production (t.ha ${ }^{-1}$ ) of maize hybrids in 2008 as affected by different nutrient supply levels in the longterm fertilization field experiment in Debrecen-Látókép, Hungary
Remarks: Fertilization levels

control: no fertilizer applied; $\mathrm{N}_{30}: 30,23,27 ; \mathrm{N}_{60}: 60$, 46, 54; $N_{90}: 90,69,81 ; N_{120}: 120,92,108 ; N_{150}: 150,115$, $135 \mathrm{~kg} \cdot \mathrm{ha}^{-1} \mathrm{~N}, \mathrm{P}_{2} \mathrm{O}_{5}, \mathrm{~K}_{2} \mathrm{O}$, respectively

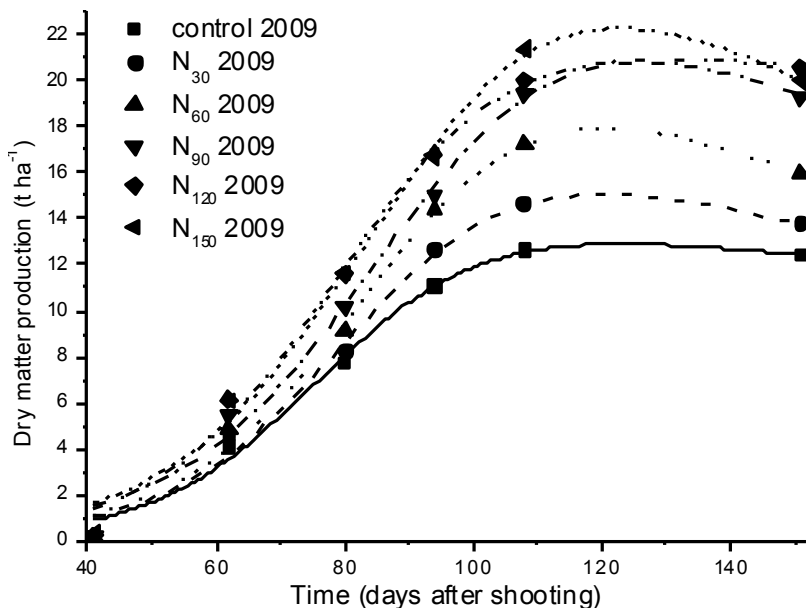

Figure 4. Dry matter production (t.ha-1 $)$ of maize hybrids in 2009 as affected by different nutrient supply levels in the long-term fertilization field experiment in Debrecen-Látókép, Hungary.

Remarks: Fertilization levels

control: no fertilizer applied; $\mathrm{N}_{30}: 30,23,27 ; \mathrm{N}_{60}: 60$, 46,$54 ; N_{90}: 90,69,81 ; N_{120}: 120,92,108 ; N_{150}: 150$, $115,135 \mathrm{~kg} \cdot \mathrm{ha}^{-1} \mathrm{~N}, \mathrm{P}_{2} \mathrm{O}_{5}, \mathrm{~K}_{2} \mathrm{O}$, respectively

\section{Potassium uptake}

It is inevitable that the potassium supply level of soils plays a major role in plant potassium uptake. At the same time, plant potassium uptake is affected by many factors (such as plant age and development state) that affect the potassium demand as well, and soil moisture and NP content. The field experiment was suitable for following the nutrient uptake dynamics of plants, but due to the limited extent of present paper only the uptake dynamics of one element can be discussed. Potassium was chosen, in case of which element both uptake and loss could be observed (SCHILLING, 2000).

The plant potassium uptake was remarkably increased by the more and more high nutrient supply levels (see Figure 5), for on the one hand the increasing NPK supply improved plant dry matter accumulation (Figure 4), on the other hand plant potassium concentration was higher in treatments with higher potassium supply. 


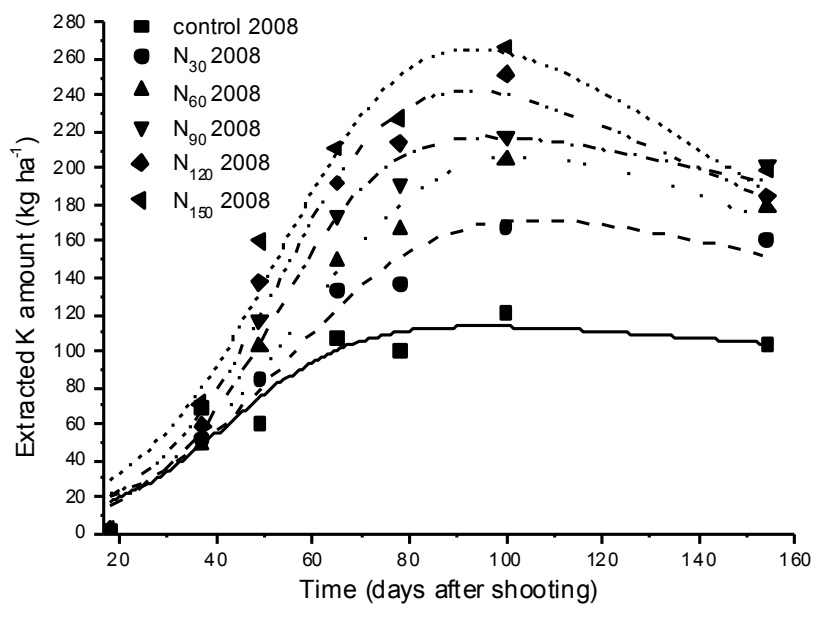

Figure 5. Potassium uptake dynamics of maize as affected by different nutrient supply levels in crop year 2008 in the long-term fertilization field experiment in Debrecen-Látókép, Hungary

Remarks: Fertilization levels

control: no fertilizer applied; $\mathrm{N}_{30}: 30,23,27 ; \mathrm{N}_{60}: 60$ 46, 54; $\mathrm{N}_{90}: 90,69,81 ; \mathrm{N}_{120}: 120,92,108 ; \mathrm{N}_{150}: 150$, $115,135 \mathrm{~kg} \cdot \mathrm{ha}^{-1} \mathrm{~N}, \mathrm{P}_{2} \mathrm{O}_{5}, \mathrm{~K}_{2} \mathrm{O}$, respectively

This two superposed effects resulted a remarkable rising of potassium uptake. The amount of potassium taken up by plants was higher in all of the treatments than the amount added with fertilization. This was especially spectacular in the control treatment (the lowest curve in Figure 5 - there was no additional potassium fertilization for 24 years!). In this case it can be observed that approximately $100 \mathrm{~kg} \mathrm{~K} \mathrm{ha}^{-1}$ was mobilized each year from the potassium stock of the chernozem soil. This proves the excellent nutrient mobilization and supplying ability of this soil type.

\section{Conclusion}

The effects of genotypes, nutrient and water supply on the dry matter production and potassium uptake dynamics of maize (Zea mays L.) were studied on chernozem soil in the DebrecenLátókép long-term field experiment (Eastern Hungary). According to the experimental results and calculations it can be concluded that - in addition to the previously used and considered soil and plant nutrient contents - the calculation of the plant-extracted nutrient amount (depending on the applied hybrid, NPK nutrient levels and water supply) is suggested to enable the characterization of the growth and nutrient demand dynamics of maize genotypes. This parameter gives information not only about the available nutrient amount at a given sampling time, but about the supply level of plants up to the sampling time as well. For the proper characterization of the mentioned dynamics of maize plants authors suggest taking the following sampling times into consideration: the intensive vegetative growth period, the switch between the vegetative and generative growth phases (silking), and the grain filling phase.

\section{REFERENCES}

BERGMANN, W. \& NEUBERT, P., 1976. Pflanzendiagnose und Pflanzenanalyse zur Ermittlung von Ernährungsstörungen und des Gesundheitszustandes der Kulturpflanzen. VEB Gustav Fischer Verlag. Jena.

BICZÓK, G., LÁSZTITY, B., BÉKÉSSY, A., RUDA, M. 1985. Modelling of dry matter and nutrient accumulation by winter wheat. Agrokémia és Talajtan. 34. Suppl. 108-119.

BUZÁs, I., 1987. Introduction to practical agrochemistry. (In Hungarian) Mezőgazdasági Kiadó. Budapest.

BUZÁs, I. (Ed.), 1988. Soil physical-chemical and chemical analytical methods. (In Hungarian) Mezőgazdasági Kiadó. Budapest.

GYŐRI, Z., SIPOS, P. \& TÓTH, Á., 2005. Changes in the quality of maize hybrids in various agricultural management systems. Acta Agron. Hung. 53. 9-15.

KÁDÁR, I. \& LÁSZTiTY, B., 1981. Changes in the nutrient ratios of winter wheat during a vegetation period. (In Hungarian) Agrokémia és Talajtan. 30. 291-306.

LÁSZTiTY, B., BiCZÓK, G., ELEK, É., RUDA, M., 1985a. The growth and nutrient turnover of maize as affected by fertilizer application. I. Dry matter accumulation, nutrient content and nutrient ratios. (In Hungarian) Agrokémia és Talajtan. 34. 137160.

LÁsZTiTY, B., BiCZÓK, G., ELEK, É., RUDA, M., 1985b. The growth and nutrient turnover of maize as affected by fertilizer application. II. Nutrient uptake. (In Hungarian) Agrokémia és Talajtan. 34. 405-420.

NAGY, J., 1997. Effect of fertilization on the yield of maize (Zea mays L.) in irrigated and non-irrigated crops. (In Hungarian) Agrokémia és Talajtan. 46. 275-288.

SCHILLING, G., 2000. Pflanzenernährung und Düngung. Verlag Eugen Ulmer. Stuttgart.

TOLNER, L., SZÉKELY, G. \& BICZÓK, GY., 1982. Methodological problems of biometrical modelling in the evaluation of soil biotests. (In Hungarian) In: $11^{\text {th }}$ Colloquium on the Use of Computer and Cybernetic Methods in Medical Sciences and Biology, Szeged. 139-145. 